短 報 Japanese Journal of Health Promotion and Physical Therapy Vol. 10, No. 2: 81-84, 2020

\title{
低座面高での端坐位姿勢が足趾把持力発揮に及ぼす影響について \\ Influence of toe-gripping action in the sitting position at low seat height
}

\author{
相馬 正之 ${ }^{1)}$, 村田 伸 ${ }^{2}$, 大田尾 浩 ${ }^{2}$, 甲斐 義浩 ${ }^{2}$ \\ 中江 秀幸 ${ }^{1}$, 佐藤 洋介 ${ }^{1)}$, 村田 潤 ${ }^{4}$
}

\author{
Masayuki Soma $^{1)}$, Shin Murata ${ }^{2)}$, Hiroshi Otao ${ }^{3)}$, Yoshihiro Kai ${ }^{22}$ \\ Hideyuki Nakae ${ }^{1)}$, Yousuke Satou ${ }^{1}$, Jun Murata ${ }^{4)}$
}

\begin{abstract}
要旨：[目的］本研究は, 適切な足趾把持力の測定肢位を検討するため, 低座面高での端 坐位姿勢が足趾把持力と足趾把持力発揮時の筋活動量に及ぼす影響を検討した。[対象・ 方法］健常成人女性 20 名を対象とした。足趾把持力の測定肢位は，股・膝関節 90 度屈曲位 座位姿勢抒よび $20 \mathrm{~cm}$ 台に着座した低座面高での端坐位姿勢の 2 条件とした。測定項目は, 足趾把持力および足趾把持力発揮時の大腿直筋と大腿二頭筋長頭および前脛骨筋と腓腹筋 内側頭の筋活動量を算出した。[結果］足趾把持力は，股・膝関節90度屈曲位座位姿勢に 比べ低座面高での端坐位姿勢が有意に低值を示した。また，低座面高での端坐位姿勢にお ける足趾把持力発揮時の筋活動は，大腿直筋㧍よび前脛骨筋の筋活動が，股・膝関節 90 度 屈曲位座位姿勢に比べ有意に高值を示した。[結語］このことから低座面高での端坐位姿 勢は，足趾把持力発揮時に拮抗筋の筋活動量が増加し，筋力発揮を妨げることで，足趾把 持力が低值を示すことが示唆された。
\end{abstract}

キーワード：足趾把持力, 低座面高での端坐位姿勢, 筋活動量

\begin{abstract}
Purpose] This study aimed to determine the influence of toe grip strength exertion in the sitting position at low seat height on toe grip strength and muscle activity in order to identify the appropriate measurement position. [Subject and Methods] The study subjects were 20 healthy women. We compared toe grip strength and muscle activity between two positions, hip and knee joints at $90^{\circ}$ flexion position on the edge of a seat and sitting position at low seat height. The activities of the following leg muscles were recorded: rectus femoris, biceps femoris, medial head of the gastrocnemius, and tibialis anterior. We then calculated the percent integrated electromyography values during toe gripping. [Results] We found that toe grip strength was significantly lower in the sitting position at low seat height than when the hip and knee joints were at $90^{\circ}$ flexion. Moreover, the percent integrated electromyography values of the rectus femoris and tibialis anterior in the sitting position at low seat height were significantly higher than those of the hip and knee joints at $90^{\circ}$ flexion. [Conclusion] The results of this study suggest that the toe grip strength in the sitting position at low seat height was kept low to inhibit the increase in muscle activity.
\end{abstract}

Key words: toe grip strength, sitting position at low seat height, muscle activity

受付日：2020年 3 月18日, 採択日：2020年 4 月17日

1) 東北福祉大学健康科学部リハビリテーション学科：テ981-8522 宮城県仙台市青葉区国見 1 - 8-1

Tel : 022-233-3111 FAX : 022-233-3113

E-mail: souma@tfu-mail.tfu.ac.jp

:1-8-1, Kunimi, Aoba-ku, Sendai-city, 981-8522, Japan Tel:022-233-3111 FAX: 022-233-3113

E-mail :souma@tfu-mail.tfu.ac.jp

2) 京都橘大学健康科学部理学療法学科

3) 西九州大学リハビリテーション学科

4) 長崎大学大学院 医歯薬学総合研究科保健学専攻 


\section{I 、はじめに}

超高齢社会に突入した我が国では，平均寿命のみな らず健康寿命を延伸させるための支援や対策が急務と なっている1)。そのため，各自治体においては介護保 険制度における各種サービスのみならず，栄養指導や 身体活動・運動指導の機会として，体力測定会の実施 など様々な取り組みがなされている。

近年, 床面に唯一接地する足部の足趾機能が重要で あるという視点から，身体機能評価の1つとして足趾 把持力の測定が行われている 趾把持力の低下は転倒リスクを2.55倍高めること卢, 自力歩行が可能な在宅障害高齢者に対し，3力月間, 4 回以上／週の頻度で足趾把持力トレーニングするこ とで足趾把持力の向上が得られ，転倒経験者数が減少 すること3)が示されている。これらのことから，足趾 把持力は転倒リスクの評価指標となりうることや足趾 把持力への介入が転倒予防に有用であることが示され ている。しかし，測定肢位の検討についての報告は少 なく ${ }^{6-9)}$, 十分な検討がなされていない。

現在，足趾把持力の測定は，端座位，体幹垂直位， 股㧍よび膝関節を 90 度屈曲し, 足関節底背屈中間位 (以 下，股・膝関節90度屈曲位座位姿勢）で行うことが多 $い^{2-5)}$ 。足趾把持力における測定肢位を検討した報告 では，座位姿勢が立位姿勢と同等に筋力発揮でき6), 足関節の肢位については，背屈位および中間位が底屈 位よりも最大発揮しやすく ${ }^{7)}$, 足部内旋位, 中間位, 外旋位の足角度変化は足趾把持力值に影響を及ぼさな いことが報告 ${ }^{8}$ されている。膝関節に焦点を当てた報 告では, 股関節90度屈曲・膝関節伸展位の測定姿勢が, 股・膝関節90度屈曲位よりも足趾把持力が低值を示す ことが報告9)されている。また，再現性の観点からは， 現行の測定肢位が立位や股関節90度屈曲・膝関節伸展 位よりもが再現性が良好であることが示されている9 以上のことから，現行の測定肢位である股・膝関節 90 度屈曲位座位姿勢は, 足趾把持力の適切な測定肢位と 考えられる。この肢位で測定するためには，個人ごと に電動昇降ベッドなどを用いて座面の高さを調整する 必要がある。しかし，体力測定会などで足趾把持力を 測定する場合，既製品の椅子を用いることが多いため， 適切な肢位が確保されていない可能性がある。座面が 高く, 測定肢位が股・膝関節90度屈曲未満の対象者に ついては台を足底に設置し調整することが可能である が，座面が低い場合は調整が困難であることが多い。 そこで本研究では, 現行の股・膝関節90度屈曲位座
位姿勢および低座面高での端坐位姿勢で測定した足趾 把持力值や下肢の筋活動量の相違を明らかにし，低座 面高での端坐位姿勢が足趾把持力と足趾把持力発揮時 の筋活動量に及ぼす影響を検討した。

\section{II. 対象・方法}

\section{1. 対 象}

対象は，健常成人女性20名とした。いずれも下肢に 整形外科的疾患や疼痛などの既往は認められなかった。 対象者の年齢は平均 $21.0 \pm 0.5$ 歳，身長は平均 $155.1 \pm$ $33.4 \mathrm{~cm}$, 体重は平均 $53.1 \pm 5.4 \mathrm{~kg}$ であった。対象者 には研究の趣旨と内容, 得られたデー夕は研究の目的 以外には使用しないこと，抒よび個人情報の漏洩に注 意することについて十分に説明し，理解を得たうえで 協力を求めた。また，研究への参加は自由意志であり， 被験者にならなくても不利益にならないことを口頭と 書面で説明し，同意を得て研究を開始した。なお，本 研究は, 所属機関の研究倫理委員会の承認 (RS 160706）を受けて実施した。

\section{2. 方 法}

測定項目は，股・膝関節90度屈曲位座位姿勢および 低座面高での端坐位姿勢から得られる足趾把持力と, その際に発揮される大腿直筋, 大腿二頭筋長頭, 前脛 骨筋，腓腹筋内側頭の筋活動量とした。

足趾把持力の測定には，足指把持力測定器（竹井機 器工業社製，T.K.K. 3362）を用いた。測定肢位は, 股・膝関節90度屈曲位座位姿勢および低座面高での端 坐位姿勢の 2 条件とした。股・膝関節90度屈曲位座位 姿勢は，端座位，体幹垂直位，股・膝関節を 90 度屈曲 位，足関節底背屈中間位とした。低座面姿勢は，730 $\mathrm{mm}(\mathrm{W}) \times 400 \mathrm{~mm}$ (D) のエクササイズブロックの $20 \mathrm{~cm}$ 台（酒井医療社製，EXB-100）を用いた座位姿 勢とした（図 1 )。なお，2 条件ともに足関節べルト で固定して測定を行った。課題遂行の順序による影響 を相殺するために，対象者毎に測定順を変えランダム に測定した。把持バーの調整は，被験者の第 1 中足趾 節関節の位置に合わせ，十分に習得させた後，休息を とりながら利き足で 2 回ずつ測定し，その最大值

（kg）を採用した。利き足の定義はボールを䟣る足 とし，対象者の全員が右側であった。

筋活動量の測定には表面筋電計（Noraxon 社製, TeleMyoG 2 )を用い，サンプリング周波数は $1,000 \mathrm{~Hz}$ とした。各筋の電極貼付部位は, Perottoの記述 ${ }^{10)} に$ 


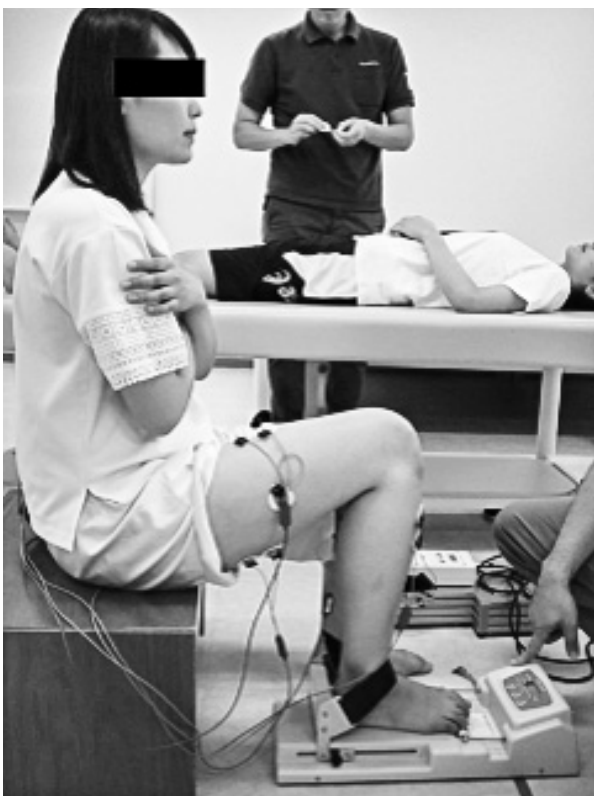

図 1 低座面高での端坐位姿勢

低座面姿勢は，730mm（W) $\times 400 \mathrm{mm（D）の工}$ クササイズブロックの $20 \mathrm{~cm}$ 台を用いた座位姿勢 とした

準じて貼付し，電極間距離は $2 \mathrm{~cm}$ とした。大腿直筋 では膝蓋骨上縁と上前腸骨棘を結んだ中点, 大腿二頭 筋長頭では腓骨頭と座骨結節を結んだ中点, 前脛骨筋 では脛骨粗面より４横指遠位部で脛骨稜より１横指外 側, 腓腹筋内側頭では膝窩皮線より 5 横指遠位部で内 側の筋腹にそれぞれ貼付した。筋電信号の導出には, 解析ソフト (Noraxon 社製, MyoResearch XP) を用 い, $20-500 \mathrm{~Hz}$ の带域通過フィルターを適応して, あ らかじめ筋電信号からノイズを除去した。導出された 筋電信号は, 全波整流処理を行ったのち, 足趾把持力 発揮 3 秒間の中間 1 秒間の積分筋電 (Integrated Electromyogram：IEMG）を求めた。得られた IEMGは, 足趾把持力発揮の測定肢位で測定した各筋の最大随意 等尺性収縮（Maximum Voluntary contraction： MVC) の值を基準に正規化（\%IEMG）を行った。

統計処理は, 統計ソフトウェア (SPSS Statistics Version 23.0, IBM 社）を使用した。2 条件における足 趾把持力および足趾把持力発揮時の大腿直筋と大腿二 頭筋長頭，前脛骨筋，腓腹筋内側頭の\% IEMG の比較 には対応のある $\mathrm{t}$ 検定を用い, 有意水準を $5 \%$ として 検討した。

\section{III. 結 果}

表 1 に股・膝関節 90 度屈曲位座位姿勢および低座面 高での端坐位姿勢における足趾把持力とその際の下肢 4 筋の $\% I E M G$ を示す。足趾把持力は, 股・膝関節90
表 1

\begin{tabular}{|c|c|c|}
\hline & $\begin{array}{l}\text { 股 - 膝関節90度 } \\
\text { 屈曲位坐位姿勢 }\end{array}$ & $\begin{array}{c}\text { 低座面高での } \\
\text { 座位姿勢 }\end{array}$ \\
\hline 持力 $(\mathrm{kg})$ & $19.6 \pm 4.8^{*}$ & $14.6 \pm 3.4$ \\
\hline 直筋（\%IEMG） & $4.7 \pm 4.1^{*}$ & $9.6 \pm 10.3$ \\
\hline 二頭筋（\%IEMG） & $24.9 \pm 12.6$ & $29.6 \pm 15.8$ \\
\hline 骨筋（\%IEMG） & $32.7 \pm 21.4^{*}$ & $39.9 \pm 18.3$ \\
\hline 内側頭（\%IEMG） & $24.5 \pm 11.6$ & $20.5 \pm 3.13$ \\
\hline
\end{tabular}

paired $t$ test

$\mathrm{n}=20$. Mean \pm standard deviation $(\mathrm{SD})$

${ }^{*} \mathrm{p}<0.05$

度屈曲位座位姿勢に比べ低座面高での端坐位姿勢が有 意に低值を示した $(\mathrm{p}<0.05)$ 。また，低座面高での 端坐位姿勢に拀ける足趾把持力発揮時の筋活動は, 大 腿二頭筋と腓腹筋内側頭には有意差が認められなかっ たが，大腿直筋と前脛骨筋の $\%$ IEMG は，股・膝関節 90 度屈曲位座位姿勢に比べ有意に高值を示した（ $\mathrm{p}<$ $0.05)$ 。

\section{IV. 考 察}

本研究では, 低座面高での端坐位姿勢が足趾把持力 と足趾把持力発揮時の筋活動量に及ほす影響を検討し た。その結果, 低座面高での端坐位姿勢では, 足趾把 持力が有意に低值を示し, 大腿直筋および前脛骨筋の $\%$ IEMG が, 股・膝関節90度屈曲位座位姿勢に比べ有 意に高值を示した。このことから低座面高での端坐位 姿勢は, 足趾把持力発揮時に拮抗筋の筋活動量が増加 し，筋力発揮を妨げることで，足趾把持力が低值を示 すことが示唆された。

本結果では，低座面高での端坐位姿勢が股・膝関節 90度屈曲位座位姿勢よりも足趾把持力が有意に低值を 示した。この要因の 1 つとして, 足関節安定性の減少 を推察した。健常成人女性が $20 \mathrm{~cm}$ 台に着座した姿勢 では，足関節が底屈位を呈す。足関節は距腿関節であ り, 距骨滑車と脛骨の下関節面, その両側に続く脛骨 の内果関節面および外果関節面 (果間関節窩) より構 成され，距骨滑車は前方より後方の幅が広いため，底 屈位では距骨滑車と果間関節窩が弱まり，関節に遊び が生じる ${ }^{11)}$ 。一方, 背屈位では, 距腿関節は果間関節 窩にはまり达むため関節の遊びは生じず，安定性が得 られる ${ }^{11)}$ 。また，足趾把持力発揮時には，踵部を支点 として足趾を屈曲するため, 足関節が背屈位へと偏位 する。しかし，低座面高での端坐位姿勢では，重心が 後方偏位するため, 足趾把持力発揮時に足関節背屈方 向への運動が生じにくく, 足関節安定性が得られない。 
これらのことが, 強い足趾把持力を発揮できない要因 と考えられた。

本研究において，低座面高での端坐位姿勢における 大腿直筋および前脛骨筋の $\%$ IEMG が，股・膝関節90 度屈曲位の座位姿勢に比べ有意に高值を示した。大腿 直筋および前脛骨筋の筋活動は, 足趾把持力発揮時に 共同作用する大腿二頭筋長頭, 腓腹筋に拮抗すること で，膝関節および足関節の安定性に寄与すると考えら れている ${ }^{12,13)}$ 。低座面高での端坐位姿勢での足趾把持 力発揮時には, 大腿直筋の筋長が静止長よりも伸長さ れ，前脛骨筋の筋長が静止長より短縮される ${ }^{14)}$ 。その ため筋力発揮時には, 筋長が静止長より減弱したこと による筋力発揮の減弱を補うため運動単位の活動増加 やインパルスの同期化 ${ }^{15}$ が生じて筋活動が高まったも のと考えられた。

本研究の結果から, 低座面高での端坐位姿勢では, 足趾把持力が低值となることが示された。そのため, 体力測定会などで低座面高の椅子を使用し得た測定值 と他の測定デー夕と比較する際は，一概に比較できな いことに留意する必要性が示された。本研究は, 皮膚 抵抗の影響やアーチファクト，近傍にある筋からのク ロストークの影響など, 表面筋電図特有の問題点があ る。また本研究の対象者は健常若年女性に限られてお り，本結果が幅広い年齢層に該当するとは限らない。 今後は，虚弱高齢者や男性など被験者による影響につ いて検討することが課題である。

\section{引用文献}

1）福永哲夫, 宮下和久：体力科学の躍進で健康づくりを支援 儿健康寿命を延伸させる。体力科学，2016，65(1)：14.

2）村田伸, 忽那龍雄 : 在宅障害高齢者の足把持力と転倒との 関連性. 国立大学理学療法士学会誌, 2003, 24：8-13.

3）村田伸, 忽那龍雄 : 在宅障害高齢者に対する転倒予防対策 一足把持力トレーニング. 日本在宅ケア学会誌，2004， 7 (2) : 67-74.

4）新井智之, 藤田博暁，細井俊希・他：地域在住高齢者にお ける足趾把持力の年齢，性別抢よび運動機能との関連．理 学療法学, 2011, 38(7) : 489-496.

5）半田幸子, 堀内邦雄, 青木和夫：足趾把握筋力の測定と立 位姿勢調整に及ぼす影響の研究. 人間工学, 2004，40（3）: 139-147.

6）中江秀幸，村田 伸，甲斐義浩・他：端座位と立位に扔け る足趾把持力と足関節周囲筋の筋活動の比較. ヘルスプロ モーション理学療法研究, 2013, 3 (1) : 11-14.

7）相馬正之, 村田 伸, 甲斐義浩・他：足関節の角度変化に よる足趾把持力の比較. ヘルスプロモーション理学療法研 究, 2013, 3 (1) : 21-23.

8) Soma M, Murata S, Kai Y, et al.: Strength and muscle ac- tivities during the toe-gripping action: comparison of ankle angle in the horizontal plane between the sitting upright and standing positions. J. Phys. Ther. Sci 28(3), 2016: 992995.

9) Soma M, Murata S, Kai Y, et al.: An examination of limb position for measuring toe-grip strength. J. Phys. Ther. Sci 26 (12), 2014: 1955-1957.

10） Aldo O. Perotto：筋電図のための解剖ガイドー四肢・体幹 一第 3 版. 西村書店, 東京, 2007, 140-155.

11） Neumann DA：筋骨格系のキネシオロジー原著第 2 版. 医歯薬出版, 東京, 2005, 636-641.

12) Soma M, Murata S, Kai Y, et al.: Activity of the Femoral Muscles during Toe-gripping Action. J. Phys. Ther. Sci 26 (10), 2014: 1619-1621.

13）相馬正之，村田 伸，甲斐義浩 - 他：足趾把持力発揮時に 扔ける下腿筋の筋活動. 理学療法科学, 2013, 28(4)：491 $-494$.

14）中村隆一 - 斉藤宏 : 基礎運動学第 6 版. 医歯薬出版, 東京, 2008, 76-78.

15）大畑光司, 市橋則明：大腿四頭筋の筋疲労による筋活動比 の変化について. 京都大学医学部保健学科紀要: 健康科学, 2006, 2 : 15-19 